\title{
Explore the Relationship between Strategy Use and ESP Reading Test Performance of Two University Majors (Humanities vs. Science)
}

\author{
Azizolah Dabaghi \\ Islamic Azad University, Najafabad Branch, Iran \\ Mahboobe Akvan \\ Islamic Azad University, Najafabad Branch, Iran
}

\begin{abstract}
This paper focuses on exploring the relationship between strategy use and ESP reading test performance of two university majors (humanities VS. science). To fulfill the purpose of the study, 240 intermediate students were selected out of a population pool of 360 ESP students studying in three universities in Iran, Esfahan based on their performance on Oxford Placement Test. After 5 sessions of teaching and practicing 8 reading comprehension strategies for instance, summarizing, linking with prior knowledge or experience, a multiple choice reading comprehension test plus a cognitive and metacognitive questionnaire were given to experimental groups. Pearson product moment correlations and $t$-test was used. The results showed the positive effect of using strategy on ESP reading comprehension test performance. Regarding major, science groups outperformed humanities. The findings have significant implications for ESP learners, teachers and material developers.
\end{abstract}

Index Terms - reading strategies, strategy, cognitive strategies, metacognitive strategies, ESP

\section{INTRODUCTION}

Language learning strategies have received a particular attention since the late 1970s. Studies showed that L2 learning could be enhanced by selecting appropriate strategies. Hosseini Nezhad (2006) found that awareness of reading strategies of Iranian students had positive effect on their performance in reading test so the outcome of the research into the strategies used by successful language learners showed that teaching strategies during language learning lead to effective learning. Although their effectiveness depends on learners. Teng (1998) also found that teaching cognitive and metacognitive leaded to improvements in comprehension. Shoery and Mokhtari (2001) also stated that strategic awareness and monitoring of the comprehension are important for efficient reading. Cohen (1998) and Macaro (2001) found that, teachers can help better to students if they know what strategies students are using. Therefore, knowledge about what goes on in students' minds during reading is very essential for teachers.

There are many factors that are important in strategy choice like learner factors, situational and social factors, and academic factors. One of the academic factors is field study. Several studies that investigated the field of study or career orientation of EFL or L2 found that there were significant differences in language learning strategy choice and use among different majors like humanities, social sciences and education on the one hand and science and technical majors on the other hand. (Mochizuki, 1999; Oxford \& Nyikos, 1989; Peacock, 2001; Peacock \& Ho, 2003; Psaltou-Joycey \& Kantaridou, 2011). The findings of another study by Oxford, Nyiko and Ehrman (1988) also revealed that engineering students choose more analytic strategies than humanities, so by reviewing literature of the study it was concluded that there were not enough researches in regard to the relationship between reading comprehension test and application of strategies between different majors in Iran, and according to Noorzadeh (2005) most of the learning teaching activities are led by the teachers and students do not have the knowledge of strategy use. According to (Tuckman, 2003) learning strategies are more important for college students because educational tasks at the college level require powerful thinking and more self reliant learning. In addition, according to (Grabe and Stoller, 2001), educational reading requires developing strategic readers who are aware of their goals in reading and able to administer strategies effectively.

The present study first, intended to explore the relationship between ESP reading comprehension test performance and the application of cognitive and metacognitive strategies. Furthermore to investigate whether there was significant difference between different university majors (humanities VS. science) in term of application of strategies in their reading comprehension test performance. So, this study was an attempt to investigate appropriate answers to the following questions:

1- Is there any significant relationship between ESP reading comprehension test performance and the application of cognitive and metacognitive strategies?

2- Is there any significant difference between different university majors (humanities VS. science) in reading comprehension test performance due to strategy use? 
To investigate the above research questions, the following null hypotheses have been addressed:

$\mathrm{H}_{01}$ : There is no significant relationship between ESP reading comprehension test performance and the application of cognitive and metacognitive strategies.

$\mathrm{H}_{02}$ : There is no difference between different university majors (humanities VS. science) regarding their reading comprehension performance due to using strategies.

\section{Methodology}

\section{Participants}

Two hundred forty male and female students aged 20-23 were screened out from among 360 ESP students from totally two majors, humanities and science in Iran, Esfahan through administering the OPT in order to choose the intermediate level. The selected participants in each major (i.e. humanities VS. Science) were randomly divided into four groups as shown in figure 1 and 2.

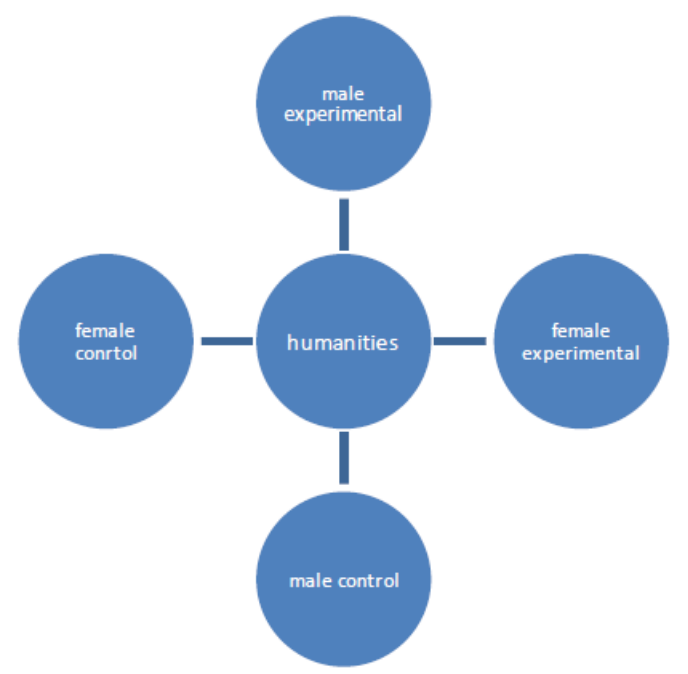

Figure 1 Humanities Groups Division

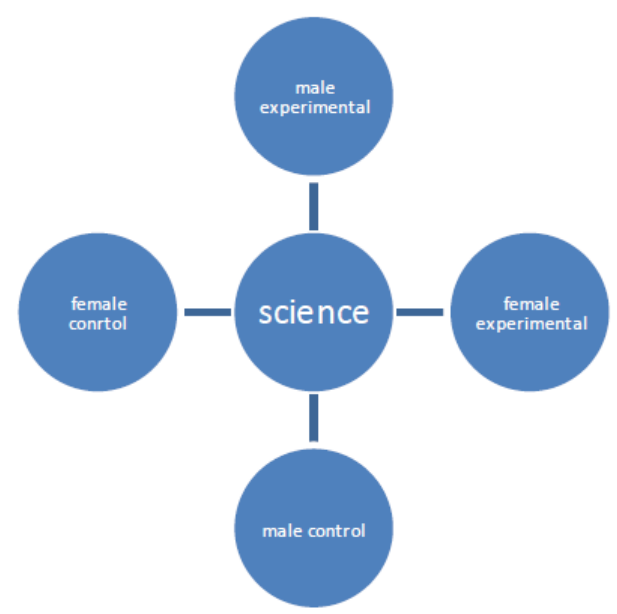

Figure 2 Science Groups Division

\section{Materials}

Several instruments were used in order to collect data. First, OPT was taken to choose the intermediate level of students. The second instrument was reading comprehension text that was according to the reading comprehension texts that were taught during the term in the class by their professor and 7 multiple choice questions related to it. Another instrument was cognitive and metacognitive questionnaire. In detail the questionnaire items in the study were similar to Purpura`s (1999), but modified to adjust a reading test.

Since, in pilot study the English form took a long time and caused problem for the participants in order to understand and complete it, the questionnaire was translated to Farsi in order to prevent misunderstanding. The questionnaire included 35 items, but items 1, 3, 10,11, 12, 13, 34, 35 were excluded due to their low item correlation and relatively low alpha. The questionnaire used a 5 Likert scale: 1 (never) 2 (sometimes), 3 (often) 4 (usually) and 5(always). Table one presents a taxonomy of cognitive and metacognitive strategy questionnaire. Nine items were related to cognitive 
strategies and eighteen items related to metacognitive strategies. Comprehending and retrieval related to cognitive strategies. Metacognitive strategies included planning and monitoring. So, students use the items that were suitable to themselves when they were reading the text and answering the questions in order to indicate how they thought.

TABLE 1

A TAXONOMY OF THE COGNITIVE- METACOGNITIVE STRATEGY QUESTIONNAIRE

\begin{tabular}{|c|c|c|}
\hline Processing & Subscale & Item used \\
\hline \multirow{2}{*}{ Cognitive } & Comprehending & $5,2,6,7,8,9$ \\
\hline & Retrieval & $4,20,28$ \\
\hline \multirow{2}{*}{ Metacognitive } & Planning & $14,16,18,21,22,24,25,29,31,32,33$, \\
\hline & Monitoring & $15,17,19,23,26,27,30$ \\
\hline
\end{tabular}

\section{Procedure}

The OPT was administered to choose the intermediate students. Then they were divided into four groups in each major. Then the selected participants in experimental groups were taught 8 reading comprehension strategies with the help of teacher, but the participants in control group did not receive any treatment. After 5 sessions of classes , the test of multiple choice reading comprehension were given into both experimental groups with the cognitive and metacognitive strategy questionnaire.

\section{Data Analysis AND Results}

Pearson product moment correlations were conducted to simply investigate the relationship between strategies and the reading test performance. Table 2 reveals the results of the correlation analyses. It should be mentioned that the correlations for different groups were calculated separately so that the researcher could see if correlation exists for each group.

TABLE 2

THE RESULTS OF THE CORRELATION ANALYSIS

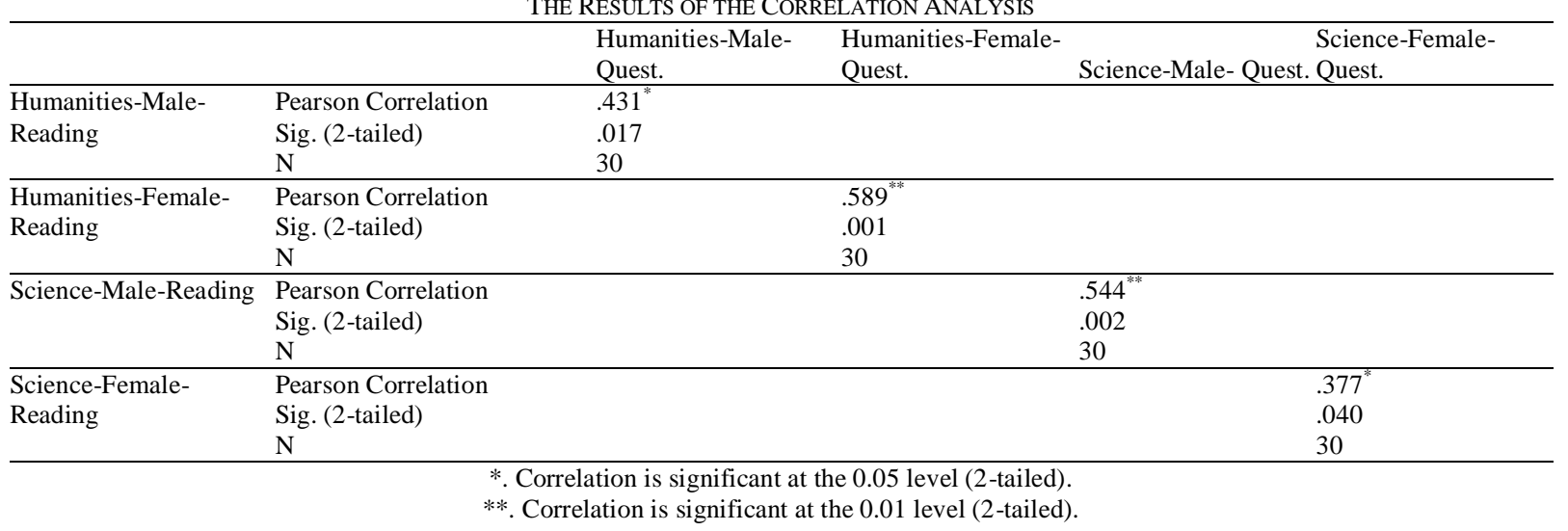

According to Table 2, there exist significant correlations for all groups (Humanities-male: $\mathrm{r}=.431, \mathrm{p}=.017$; Humanities-female: $r=.589, p=.001$; Science-male: $r=.544, p=.002$; Science-female: $r=.377, p=.040)$. The Pearson product moment correlations revealed that there was significant relationship between reading comprehension test results and employing cognitive and metacognitive strategies in the test of reading. Therefore, the first hypothesis stating that, "there is no significant relationship between EFL reading comprehension test performance and the application of cognitive and metacognitive strategies" can also be rejected, and it can be claimed that there is a significant relationship between reading comprehension test results and employing cognitive and metacognitive strategies in the test of reading.

A $t$ - test was employed to find out the differences between different university majors regarding their reading comprehension performance due to using strategies. The $t$-test results demonstrated that different university majors perform differently on the test of reading comprehension regarding employing reading strategies. Table 2 presents the descriptive statistics for this comparison, and Figure 3 presents the means graphically.

TABLE 3

DESCRIPTIVE STATISTICS FOR HYPOTHESIS TWO

\begin{tabular}{lllll}
\hline Group & $\mathrm{N}$ & Mean & SD & SEM \\
\hline Humanities & 60 & 14.20 & 2.516 & .325 \\
Science & 60 & 15.20 & 2.517 & .325
\end{tabular}




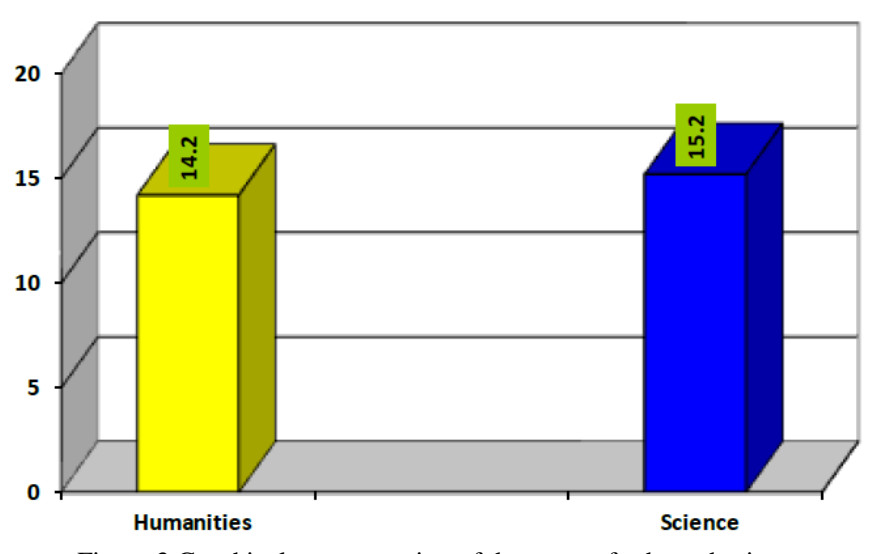

Figure 3 Graphical representation of the means for hypothesis two

The data in Table 3 reveals that there is some difference between the two means. In order to make sure that this difference is statistically significant, $t$-test was employed. Table 4 depicts the results of this $t$-test.

TABLE 4

THE RESULTS OF T-TEST FOR HYPOTHESIS TWO

\begin{tabular}{llll}
\hline $\mathrm{t}$ & $\mathrm{df}$ & Sig. & Mean Difference \\
\hline-2.177 & 118 & .032 & -1.00 \\
\hline
\end{tabular}

According to Table 4, the amount of t-observed (-2.177) is significant at the probability level of $\mathrm{p}=.032$ which denotes a statistically significant amount. In other words, since t-observed is negative, it means that the participants in science group outperformed the participants in humanities group.

\section{DiscuSSIONS AND CONCLUSIONS}

The correlational between reading comprehension scores and the results of the questionnaire for each group was significant . The participants in the experimental groups who were exposed to strategy instruction highly outperformed the control group who taught reading comprehension through traditional way (i.e. without teaching and practicing strategies).The selected participants were taught 8 reading comprehension strategies for instance, previewing or over viewing tasks, evaluating their thought, making prediction, translating, summarizing, linking with prior knowledge or experience, applying grammar rules and guessing meaning from contexts in five sessions and every session thirty minutes with the help of their professor then practiced the strategy in the text of their reading comprehension. The researcher explicitly explained what a strategy is, and with the help of teacher modeling how to use it; students applying the strategy in the reading comprehension text. In a research conducted by McNawara et al. (2006), improving students' strategies critically led to a better reading comprehension, so in this study the researcher explained the reading strategies to experimental groups. Although because of time limitation the researcher requested the students in experimental group to apply the strategies autonomously in other contexts at home.

Therefore, the above mentioned results seem to reject the hypotheses of the study and they revealed that there was significant relationship between ESP reading comprehension test performance and the application of the cognitive and metacognitive strategies. Hosseini Nezhad, (2006); Malcome, (2009); Park, (2010); uzunmak, (2005); Zhang \& Wu, (2009) also showed that high achievement in reading comprehension is correlated with the high use of reading strategies. Therefore, if teachers explicitly teach reading strategies, it would help students to perform good reading habits in order to success in academic reading.

The results of $t$-test indicated that participants in science group highly outperformed the participants in humanities group. Therefore, the second null hypothesis which stated that "there was no difference between different university majors regarding their reading comprehension performance due to using strategies" rejected, so it can be stated that different university majors perform differently on the test of reading comprehension regarding employing strategies. This is due to the findings of Nyikos and Ehrman(1988). They indicated that engineering students choose more analytic strategies than the humanities students do.

Another study (Peacock \& Ho, 2003) that compared learners of eight disciplines (building and construction, business, computer studies, engineering, English, math, primary education, science), Learners of English demonstrated the highest frequency of strategy use, especially cognitive, metacognitive and social strategies.

There were several reasons for high performance of science groups in comparison to humanities.

The first one was that the science groups may be having more aptitude than humanities. The tendency factor will show a strong relationship with second language proficiency in monitored test situations and when conscious learning has been stressed in the classroom. Gardner (1960) concluded that aptitude is a necessary factor in the acquisition of second language learning skills .Carroll(1963) defined aptitude as degree of learning, i.e. Learners that have higher aptitude will learn faster than learner with lower aptitude. So besides age, ability seems to be the best predicator in adult 
second, third, fourth language .Carroll (1962) believed that aptitude in foreign language refers to talent or a group of talents separated from intelligence. Oxford (1995) found that among individual differences, it is language aptitude that correlated most closely with foreign language performance.

Another reason was that maybe the science major had higher motivation, thus, they strived to do well. Motivation seems to have a very correlation with overall marks and marks in reading, writing and listening, but not as high in speaking. So, it can consider as one of the most significant predicator of overall performance in English as a foreign language. (Mounawar Al Sayed, 2003). Gardner and Lambert (1972) reported that aptitude and motivation have a great influence on second language acquisition. Burstall, et al. (1974), Backman (1976), and others have implied that high achievement causes positive manner and high motivation, while the Gardner (1985) model explicitly suggests correspondence between these variables.

Another reason, maybe related to the left hemisphere that is related to the language, logical, and rational facts and the science students mostly use the left hemisphere of the brain and they analyses the facts better than humanities.

Another related to multiple intelligence (MI) that focuses on differences between learners and the need to recognize learner differences in teaching. MI is based on the work of Gardner.

Gardner (1985) posits eight native intelligences as follows:

1- Linguistics

2- Logical/mathematical

3- Spatial

4- Musical

5- Bodily/kinesthetic

6- Interpersonal

7- Intrapersonal

8- Naturalist

Engineers have the logical, mathematical intelligence, so their ability in thinking rationally is stronger in comparison to the humanities major.

The people who use their left hemisphere more can understand text better, they also can analyses things and their rational, science, and mathematics are better so maybe because of these reasons the science groups performed better in their reading comprehension test performance because they maybe use the strategies effectively and understand the text more. They also noticed the details more, because the other groups (humanities) paid attention to general facts and did not apply strategies in detail to help them understand the text better.

Another reason may be related to the nature of the books. The natures of science books were different from humanities.

In conclusion, the purpose of this research was to explore the relationship between cognitive and metacognitive strategies use and reading comprehension test of two university majors. The study was implemented across three universities between two university majors (humanities VS. science). There was an important relationship between the results of reading comprehension test and employing cognitive and metacognitive strategies in the test of reading. Moreover, science groups performed better than humanities in their reading comprehension performance, so it can be stated that if ESP teachers embed strategies into everyday class activities it encourages students to use strategies in order to increase their comprehension. So, this study may have some hints for English teacher and ESP learners. It would also have some implications for material developers in order to understand the learner's need and make English language learning more learner centered.

\section{IMPLICATIONS OF THE STUDY}

This study investigated the cognitive and metacognitive strategies which were used by intermediate students across totally two majors (science V.S. Humanities).The results of the study showed the positive effect of strategies on reading comprehension test performance of ESP learners.

This study, according to the obtained results, may have some hints for English teachers who might, for sure, pay attention to teaching strategies and practicing during reading comprehension. Since it is highly recommended that L2 teachers and material developers understand L2 learning needs of different individual learners (Hutchinson \& Waters,1987); EFL and specially ESP classroom teachers and material developers should know their learners language learning process in order to understand their students learning needs and make English language learning more individualized and learner centered. Teachers should know that applying strategies by learners would improve their reading comprehension. So it persuades ESP classroom teachers to understand their students need and make the class more learner centered instead of just teach according to the traditional ways like read the text, explain and translate it. The findings of this study will encourage teachers of EFL in ESP classes to the explicit teaching of reading strategies in order to help students promote reading strategies and design good reading manners. Although learning strategies help to develop learning, but it's better to use eclectically, in conjunction with other techniques, Griffiths (2001). The suggested point also for teachers in school and language centers and institutes is that they change the way they teach and assess the students and move toward a more learner-oriented method or approach. 
The findings of this study would also have implications for ESP learners in that they would be informed about their English reading strategic processes; increase their confidence and enables them to self-regulate their own learning (Winograde, 1990). It also encourages students that in order to succeed in academic reading, it's necessary that they get familiar with reading strategies, however according to some researchers like cohen (2003, 2007), Grable (2004), Hdwine, Winne, stockley, Nisbit, Woszczyne (2001), Paris (2002) and Zhang (2003) strategies are not absolutely good or bad but it depends on the learners in order to use strategies powerfully or uselessly in different situations.

The other implication is for EFL learning program in order that the ESP books and materials should developed base on strategy training and learners should have a more active role in their learning process.

\section{SUGGESTIONS FOR FURTHER RESEARCH}

This study intended to explore the relationship between ESP reading test performance and cognitive and metacognitive strategy use. It was done between two majors (i.e. humanities and engineering science).

The following are some tentative suggestions for future research:

1- The researcher collected data from two university majors, therefore subsequent research could be done with participants from other fields of study.

2-The researcher considered cognitive and metacognitive strategies which is not enough; therefore the future research could consider the effect of other strategies on reading comprehension test.

3-The same study could be done in order to collect the data through triangulation in order to gain more valid results.

\section{APPENDIX A}

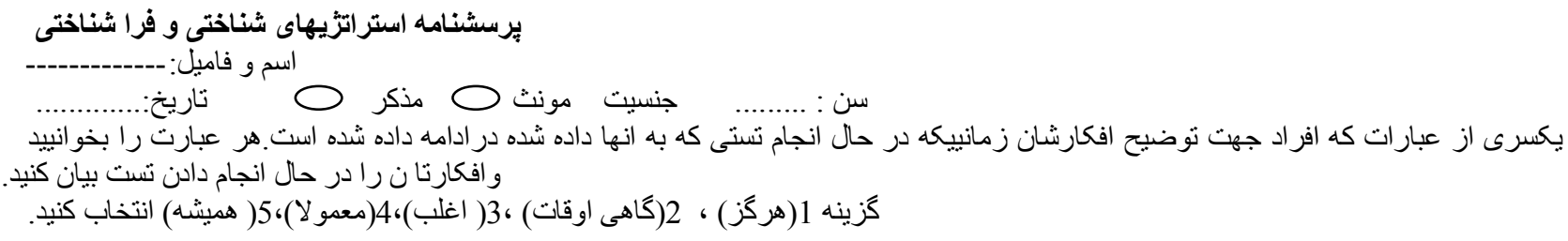

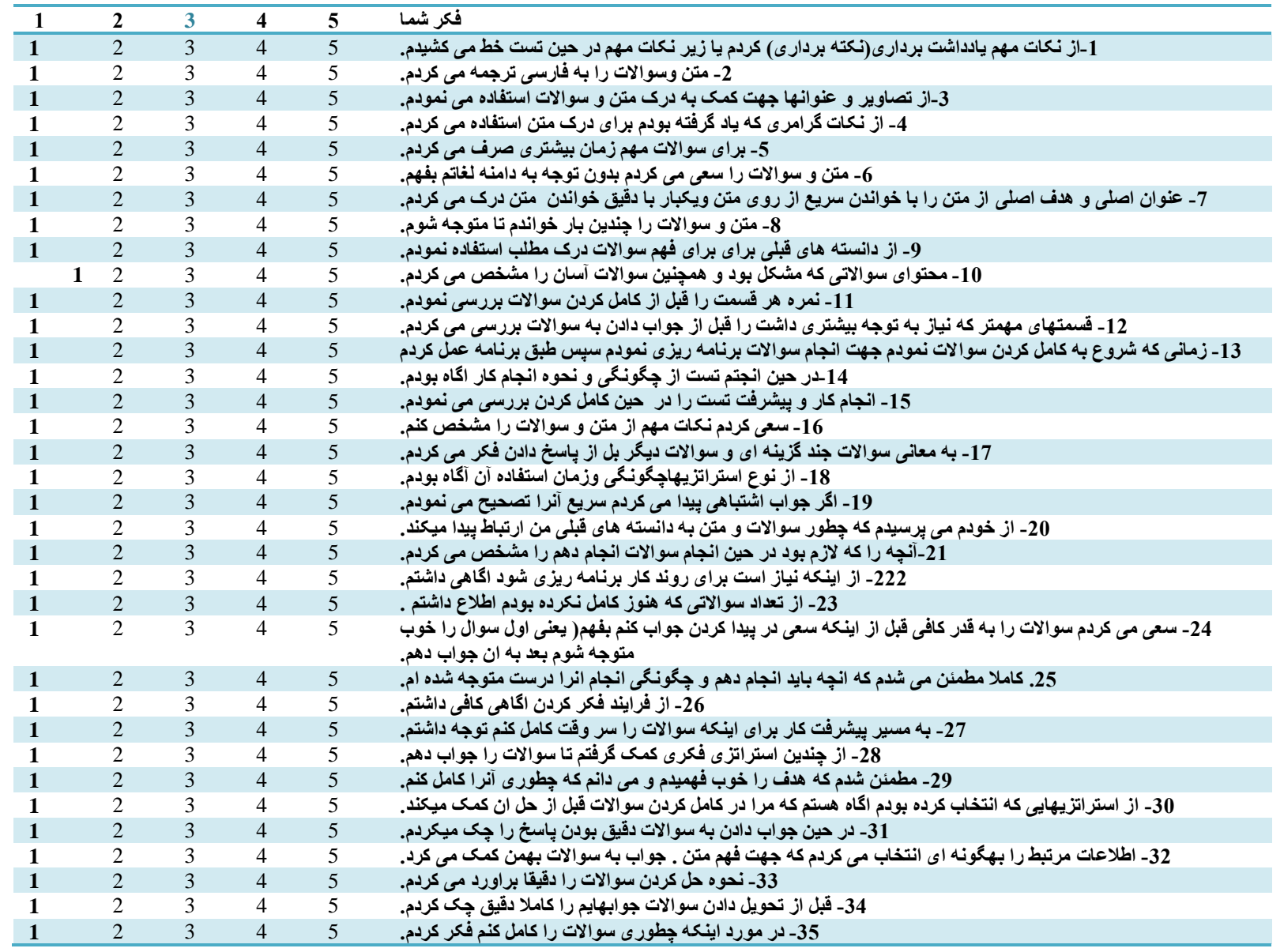




\section{REFERENCES}

[1] Backman, N. (1976). Two measures of affective factors as they relate to progress in adult second- language learning. Working Papers on Bilingualism, 10, 100-122.

[2] Bachman, L. F., \& Cohen, A. D. (1998). Language testing-SLA interfaces: An update. In L. F. Bachman \& A. D. Cohen (Eds.), Interfaces between second language acquisition and language testing research. New York, UK: Cambridge University Press.

[3] Burstall, C., Jamieson. M., Cohen, S., \& Hargreaves, M. (1974).Primary French in the Balance, Windsor: NFER Publishers, 243.

[4] Carroll, J. B. (1962). The prediction of success in intensive foreign languaeg training. In R. Glaser (Ed.), Training research and education. Pittsburgh: University of Pittsburgh Press.

[5] Cohen, A. (1998). Strategies in learning and using a second language. Harlow, UK: Longman.

[6] Cohen, A. D. (2003). The learner's side of FL learning: where do styles, strategies and tasks meet? International Review of Applied Linguistics in Language Teaching, 41(4) 279-293.

[7] Cohen A. D. (2007). Coming to terms with language learner strategies: Surveying the experts. In Cohen \& E. Macaro (Eds.), Language learner strategies: 30 years of research and practice (pp. 29-45). Oxford, UK: Oxford University Press.

[8] Gardner, R. C. (1985a). Social psychology and second language learning: The role of attitudes and motivation. London: Edward Arnold Publishers.

[9] Gardner, R. C. (1960). Motivational variables in second-language acquisition. Doctoral dissertation. McGill University,

[10] Gardner, D. B. \& Lambert, W. E. (1972). Attitudes and Motivation in Second Language Learning. Massachusetts: Rowley

[11] Gardner, R. C., Moorcroft, R., \& Metford, J. (1989). Second language learning in an immersion programme: Factors influencing acquisition and retention. Journal of Language and Social Psychology, 8, 287-305.

[12] Grabe, W. \& Stoller, F. (2001).Reading for academic purposes: Guidelines for theESL/EFLteacher. In M.Celce-Murcia (Ed.), Teaching English as a second or foreign language, ( pp.187-203). Boston: Heinle \& Heinle.

[13] Grable, J. E., \& Joo, S-H. (2004). Environmental and biopsychosocial factors associated with financial risk tolerance. Financial Counseling and Planning, 15 (1), 73-88.

[14] Griffiths, C. \& Parr, J. M. (2001): Language Learning Strategies: Theory and Perception.ELT Journal, 53(3), $247-54$.

[15] Hadwin, A. F., Winne, P. H., Stockley, D. B., Nesbit, J. C., \& Woszczyna, C. (2001). Context moderates students' self-reports about how they study. Journal of Educational Psychology, 93, 477-488.

[16] Hosseini Nezhad, N. (2006). On the meta-cognitive awareness of reading strategies and the reading comprehension of Iranian non-English major university students. Unpublished Master's thesis, Al-Zahra University, Tehran, Iran.

[17] Hutchinson, T., \& Waters, A. (1987). English for Specific Purposes: A learning centered approach. Cambridge: Cambridge University Press.

[18] Kantaridou, Z. (2004). Motivation \& Involvement in Learning English for Academic Purposes. Unpublished PhD Thesis, Department of English Language.

[19] Macaro, E. (2001). Learning strategies in foreign and second language classrooms. London: Continuum.

[20] Malcolm, D. (2009). Reading strategy awareness of Arabic-speaking medical students studying in English. System, vol. 37, pp. 640-651.

[21] McMullen, M. (2008). Gender, Academic Major, Language Learning Strategies, and the Potential for Strategy Instruction in Saudi Arabia. Unpublished Master's Dissertation, University of Manchester, England.

[22] McNamara, D.S., O'Reilly, T.P., Best, R.M., \& Ozuru, Y. (2006). Improving adolescent students' reading comprehension with iSTART. Journal of Educational Computing Research, 34(2), 147-171.

[23] Mochizuki, A. (1999). Language learning strategies used by Japanese university students. RELC Journal, 30(2), 101-113.

[24] Mounawar A. S. (2003). Factors That Contribute to Success in Learning English as a Foreign Language. Damascus University Journal, $19,1+2$

[25] Nourzadeh, A. (2005). On the relationship between Iranian EFL learners' gender and their use of read ing strategies at high schools. Retrived May5, 2013, from www.teo.ir.

[26] Oxford, R. \& Burry-Stock, J. A. (1995). Assessing the use of language learning strategies worldwide with the ESL/EFL version the strategy inventory for language learning (SILL). System, 23(1), 1-23.

[27] Oxford, R.L., \& Burry-Stock, J.A. (1995). Assessing the use of language learning strategies worldwide with the ESL/EFL version of the Strategy Inventory for Language Learning. System, 23(2), 153-175.

[28] Oxford, R., \& Nykios, M. (1989). Variables affecting choice of language learning strategies by university students. Modern Language Journal, 73(3), 291-300.

[29] Oxford, R. L., Nyikos, M., \& Ehrman, M. (1988). Vive la difference? Reflections on sex differences in use of language learning strategies. Foreign Language Annals, 21(4), 321-329.

[30] Paris, S. G. (2002). When is metacognition helpful, debilitating, or benign? In P. Chambers, M. Izaute \& P. Marescaux (Eds.), Metacognition: Process, function and use (pp.105-121). Boston, MA: Kluwer Academic.

[31] Paris, S.G., \& Winograd, P. (1990). How metacognition can promote academic learning and instruction. In B.F. Jones \& L. Idol (Eds.), Dimensions of thinking and cognitive instruction (pp. 15-51). Hillsdale, NJ: Lawrence Erlbaum.

[32] Park, Y. (2010). Korean EFL college students' reading strategy use to comprehend authentic expository/technical texts in English. Unpublished Doctoral dissertation, University of Kansas, United States.

[33] Peacock, M. (2001). Pre-service ESL teachers' beliefs about second language learning: A longitudinal study. System, $29,177-$ 195.

[34] Peacock, M., \& Ho, B. (2003). Student language learning strategies across eight disciplines. International Journal of Applied Linguistics, 13(2), 179-200.

[35] Phakiti, A. (2003a). A closer look at gender differences in strategy use in L2 reading Language learning. Language testing $.53 / 4$ 
[36] Phakiti, A. (2003b). A closer look at the relationship of cognitive and metacognitive strategy use to EFL reading achievement test performance. Language testing. 20/1.

[37] Politzer, R.L. (1983). An exploratory study of self-reported language learning behaviors and their relation to achievement. Studies in Second Language Acquisition, 6, 54-67.

[38] Psaltou-Joycey, A. (2003). Strategy use by Greek university students of English. In E. Mela-Athanasopoulou (ed.) .Selected papers on Theoretical and Applied Linguistics, 15th International Symposium, 4-6 April 2001. Department of Theoretical and Applied Linguistics. School of English. Aristotle University of Thessaloniki, 591-601.

[39] Psaltou-Joycey, A. \& Z. Kantaridou. (2011). Major, minor, and negative learning style preferences of university students. System 39/1.

[40] Purpura, J.E. (1999). Learner strategy use and performance on language tests: A structural equation modeling approach. Cambridge: Cambridge University Press.

[41] Sheorey, R. \& Mokhtari, K. (2001). Differences in the metacognitive awareness of reading strategies among native and nonnative readers. System, 29(4), 431-449.

[42] Soi Meng, P. (2006). Strategy use in advanced EFL readers: Identifying and characterizing the patterns of reading strategies employed by tertiary EFL students. Unpublished Doctoral dissertation, Chinese University of Hong Kong.

[43] Teng, H. (1998). An investigation of EFL listening strategies. Paper TESOL, Seale.

[44] Tuckman, B. W. (2003).The effect of learning and motivation strategies training on college students' achievement. Journal of College Student Development, 44,430-437.

[45] Uzuncakmak, P. (2005). Successful and unsuccessful readers' use of reading strategies. Unpublished Master's thesis, Bilkent University, Ankara, Turkey.

[46] Zhang, L. J. (2003). Research into Chinese EFL learner strategies: Methods, findings and instructional issues. RELC Journal: $A$ Journal of Language Teaching and Research, 34, 284-322.

[47] Zhang, L. J., \& Wu, A. (2009). Chinese senior high school EFL students' metacognitive awareness and use of reading strategies. Reading in a Foreign Language, 21(1), 37-59.

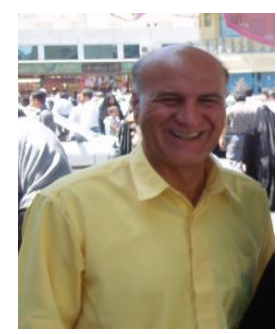

Azizolah Dabaghi is currently involved in teaching various subjects in SLA at the University of Isfahan. He is particularly interested in teaching and research in psycholinguistics and second language culture.

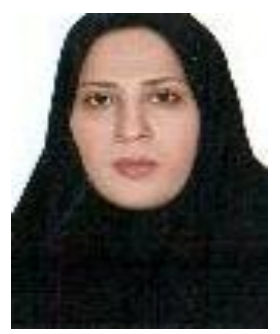

Mahbobe Akvan was born in Iran, Esfahan in1980. She got B.A. in English Language teaching from Najafabad Azad University in 2002 and her M.A. in teaching English as a foreign Language from Najafabad Azad University in 2013. Having an eleven -year period of experience in teaching English at school. She has also taught English at various levels to different age groups for 15 years in private institute in Esfahan. She is teaching in Educational system in Esfahan now. 